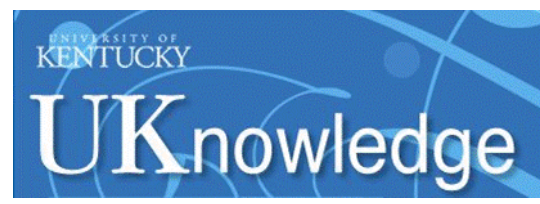

University of Kentucky

UKnowledge

$1-2005$

\title{
Prevalence of Obesity and Lack of Physical Activity Among Kentucky Adolescents
}

Hatim A. Omar

University of Kentucky, hatim.omar@uky.edu

Kristin Rager

University of Kentucky

Follow this and additional works at: https://uknowledge.uky.edu/pediatrics_facpub

Part of the Pediatrics Commons, and the Public Health Commons

Right click to open a feedback form in a new tab to let us know how this document benefits you.

\section{Repository Citation}

Omar, Hatim A. and Rager, Kristin, "Prevalence of Obesity and Lack of Physical Activity Among Kentucky Adolescents" (2005). Pediatrics Faculty Publications. 80.

https://uknowledge.uky.edu/pediatrics_facpub/80

This Article is brought to you for free and open access by the Pediatrics at UKnowledge. It has been accepted for inclusion in Pediatrics Faculty Publications by an authorized administrator of UKnowledge. For more information, please contact UKnowledge@lsv.uky.edu. 


\section{Prevalence of Obesity and Lack of Physical Activity Among Kentucky Adolescents}

Digital Object Identifier (DOI)

https://doi.org/10.1515/IJAMH.2005.17.1.79

Notes/Citation Information

Published in International Journal of Adolescent Medicine and Health, v. 17, no. 1, p. 79-82.

(c) Freund Publishing House Ltd.

The copyright holder has granted permission for posting the article here.

Reprinted as a book chapter in Obesity and Adolescence: A Public Health Concern. Hatim A Omar, Donald E. Greydanus, Dilip R. Patel, \& Joav Merrick, (Eds.). p. 107-110.

Reprinted as a book chapter in Adolescent Behavior Research: International Perspectives. Joav Merrick, \& Hatim A. Omar, (Eds.). p. 115-118. 


\title{
Prevalence of obesity and lack of physical activity among Kentucky adolescents
}

\author{
Hatim A Omar, MD and Kristin Rager, MD
}

Section of Adolescent Medicine, Department of Pediatrics, University of Kentucky,
Lexington, KY, United States of America

Abstract: Lack of physical activity and overweight status continues to be a significant health problem in the United States. To assess the actual prevalence of thèse problems, we reviewed data from the School-based Health Promotion Centers in one middle school, and one High school in central Kentucky. A total of $2326^{\text {th }}$ graders and $6079^{\text {th }}$ graders were included. A total of $92 \%$ of $6^{\text {th }}$ graders and $45 \%$ of $9^{\text {th }}$ graders reported complete lack of regular exercise. $37 \%$ of $9^{\text {th }}$ graders and $59 \%$ of $6^{\text {th }}$ graders had inappropriate nutrition, $47 \%$ of $9^{\text {th }}$ graders and $33 \%$ of $6^{\text {th }}$ graders had Body Mass Index over the $85^{\text {th }}$ percentile for age. Among overweight adolescents, only $16 \%$ of $9^{\text {th }}$ graders and $1 \%$ of $6^{\text {th }}$ graders thought they were overweight. Since the body mass index data is derived from actual objective measurement, we conclude that overweight status is a significant problem in Kentucky and that the actual numbers may be higher than those reported for the State based on surveys and estimates. Furthermore, many adolescents are not aware of their weight problem and most of them do not participate in regular exercise.

Keywords: Adolescents, Youth obesity, Physical activity, risk taking behavior, Body Mass Index

Correspondence: Hatim Omar, MD, Professor of Pediatrics and Obstetrics/Gynecology, Department of Pediatrics, Kentucky Clinic, Rm. J422, Lexington, KY 40536-0284, USA. Tel. 859-323-5643; FAX; 859-257-7706; Email: haomar2@uky.edu

Received: October 02, 2004. Revised: December 14, 2004. Accepted: December 14, 2004.

\section{INTRODUCTION}

Overweight and obesity among adolescents have been referred to as a worldwide epidemic (1). The World Health Organization (WHO) defines overweight as a body mass index (BMI) of over $25 \mathrm{~kg} / \mathrm{m} 2$ and obesity as a BMI of over $30 \mathrm{~kg} / \mathrm{m} 2$ (2). The 2003 Youth Risk Behavior Survey (YRBS) found that $13.5 \%$ of American students were overweight. Overall, the prevalence of being overweight was higher among male $(17.4 \%)$ than female $(9.4 \%)$ students, and higher annong black $(17.6 \%)$ than white $(12.2 \%)$ students. $29.6 \%$ of students described themselves as slightly or very overweight and $43.8 \%$ reported they were trying to lose weight. Overall, the prevalence of trying to lose weight was higher among female $(59.3 \%)$ than male $(29.1 \%)$ students and highest among white females $(62.6 \%)(3)$.

The United States Department of Agriculture (USDA) and the United States Department of Health and Human Services (HHS) recommend that children and adolescents engage in at least 60 minutes of physical activity per day (4). However, according to the 2003 YRBS, $33.4 \%$ of students nationwide participated in insufficient physical activity in the previous week and $11.5 \%$ had not participated in either vigorous physical activity or mod- 
erate physical activity at all (5).

$57.1 \%$ of students nationwide had exercised to lose weight or to keep from gaining weight during the 30 days preceding the survey. $42.2 \%$ of students had eaten less food, fewer calories, or foods low in fat to lose weight or to keep from gaining weight and $13.3 \%$ had gone without eating for over 24 hours to lose weight or to keep from gaining weight. During the 30 days preceding the survey, $9.2 \%$ of students had taken diet pills, powders, or liquids without advice from a physician and $6 \%$ had vomited or taken laxatives to lose weight or to keep from gaining weight (3).

Only $22.0 \%$ of American students reported eating fruits and vegetables over five times/day during the seven days preceding the survey (5), as recommended by the USDA and HHS (6). The health risks of overweight and obesity are significant, including cardiovascular disease (7), type II Diabetes (8), orthopedic issues such as slipped capital femoral epiphysis, pulmonary issues such as obstructive sleep apnea, and psychosocial pathology such as depression and poor self-esteem (9).

Poor nutrition and decreased levels of activity are widely touted as the causes of the epidemic of overweight and obesity in the United States. In this study, we evaluated weight, nutrition, weight perception and exercise status in middle and high school students in Central Kentucky.

\section{METHODS}

School-Based Health Promotion Centers (SBHC) in one middle school and one high school in Central Kentucky were utilized for this study. SBHC screen all students entering middle $\left(6^{\text {th }}\right.$ grade) and high $\left(9^{\text {th }}\right.$ grade) school for all risk taking behaviors. Students are excluded if their parents do not give consent for confidential screening. Data from these screenings were collected from the years 2002 and 2003. Body Mass
Index (BMI) was calculated by dividing the actual weight in kilograms by the height in square meters. The rest of the information was obtained by interviewing the students using the Perkins Adolescent Risk Screen (PARS)(10,11).

\section{RESULTS}

During the years 2002 and 2003, a total of $2326^{\text {th }}$ graders (105 females and 127 males) and $6079^{\text {th }}$ (306 females and 301 males) graders were screened. Only $23 \%$ of females and $9 \%$ of males among $9^{\text {th }}$ graders and $1 \%$ of females and $1.5 \%$ of males of $6^{\text {th }}$ graders perceived themselves as overweight. $51 \%$ of $9^{\text {th }}$ graders and $53 \%$ of $6^{\text {th }}$ graders reported spending more than four hours on non-school days and more than two hours on school days on sedentary activities (watching television or using computers or video games). Poor nutrition was defined as eating mostly fast food, not eating fruit and vegetables and/or consuming too many unhealthy snacks and carbonated beverages. Exercise was defined as a minimum 20 . minutes of vigorous physical activity at least five days every week. The prevalence of abnormal BMI, poor nutrition and lack of exercise is shown in table 1.

\section{DISCUSSION}

This study was a simple descriptive one that did not address causes or management of obesity. It did not look at ethnic or socioeconomic differences. The goal was to assess the extent of obesity and lack of physical activity among middle and high school students in the area. Most available data is usually derived from subjective surveys, which may overstate or understate facts. Adolescents responding to written surveys may sometimes fail to understand the questions. In our SBHC, adolescents were interviewed one on one by the same trained professional, allowing for more 
Table 1. BMI, Nutrition and exercise among Kentucky adolescents

\begin{tabular}{lcccc}
\hline & \multicolumn{2}{c}{$9^{\text {th }}$ Graders } & \multicolumn{2}{c}{$6^{\text {th }}$ Graders } \\
& Males & Females & Males & Females \\
\hline BMI 85\%-95\% & $32 \%$ & $30 \%$ & $21 \%$ & $22 \%$ \\
BMI $>95 \%$ & $13 \%$ & $20 \%$ & $13 \%$ & $9 \%$ \\
Poor Nutrition & $24 \%$ & $50 \%$ & $61 \%$ & $57 \%$ \\
No Exercise & $37 \%$ & $54 \%$ & $92 \%$ & $92 \%$ \\
\hline
\end{tabular}

consistency. Objective measurement of weight and height were also obtained. Our results showed a similar percentage of obese adolescents $(16.5 \%)$ to that reported by CDC (14.6\%) for Kentucky (12) in high school students. In this study, an additional $31 \%$ were at risk for obesity with BMI $>85 \%$. Among middle school students these numbers were slightly better (see table 1). One disturbing result in the study was the low percentage of students in both groups who correctly perceived their weight as inappropriate. When exact parameters for exercise were explained to students, the majority in both groups showed lack of regular exercise (Table 1). A similar percentage of students had poor nutrition habits.

\section{CONCLUSIONS}

Based on these results we conclude that sedentary life-style, lack of regular exercise and poor nutrition are very prevalent in Kentucky adolescents. Furthermore, many adolescents do not recognize their weight problem as such. Education of adolescents, their parents, teachers, and the community is needed to help prevent further increases of these problems.

\section{REFERENCES}

1. Kohn M. The worldwide epidemic of obesity in adolescents. Adolesc Med 2003;14(1):1-9.
2. http://www.who.int/dietphysicalactivit y/media/en/gsfs obesity.pdf Accessed December 3, 2004.

3. Centers for Disease Control and Prevention. Surveillance Summaries, May 21, 2004. MMWR 2004;53:25-7.

4. United States Departments of Agriculture and Health and. Human Services. Nutrition and Your Health: Dietary Guidelines for Americans, Fifth Edition. Washington, DC: Authors, 2000:13-4.

5. Centers for Disease Control and Prevention. Surveillance Summaries, May 21, 2004. MMWR 2004;53:21-4.

6. United States Departments of Agriculture and Health and Human Services. Nutrition and Your Health: Dietary Guidelines for Americans, Fifth Edition. Washington, DC: Authors, 2000:16-7.

7. Smith JC. The current epidemic of childhood obesity and its implications for future coronary heart disease. Pediatr Clin North Am 2004;(51) 6:1679-95.

8. Goran MI. Obesity and risk of Type 2 diabetes and cardiovascular disease in children and adolescents. J Clin Endocrin Metabol 2003;88(4):1417-27.

9. Brown WM. Obesity in children and adolescents. Clin Fam Pract 2002; 4(3):603-13.

10. Perkins K, Ferrari N, Rosas A, 
Bessette R, Williams A, Omar H. You won't know unless you ask: the biopsychosocial interview for adolescents. Clin Ped 1997;36:79-86.

11. Adams C, Perkins K, Lumley V, Hughes C, Burns J, Omar H. Validation of the Perkins Adolescent Risk
Screen (PARS). J Adolesc Health 2003;33:462-70.

12. Centers for Disease Control and Prevention. Surveillance Summaries, May 21, 2004. MMWR 2004;53: Figure 8.

\section{BITS 'N PIECES}

How adolescents construct their future: the effect of loneliness on future orientation

Abstract This study examined the effect of loneliness, gender, and two dimensions of prospective life domains on adolescent future orientation. Future orientation was studied in four prospective domains: social relations, marriage and family, higher education and work and career. These domains are described in terms of two dimensions: theme (relational vs. instrumental) and distance (near vs. distant future). Data collected from Israeli Jewish adolescents (11 th graders) were analysed by repeated measures ANOVAs and ANCOVAs (covariate: depressive experiences) for seven future orientation variables: value, expectance, control (motivational variables), hopes, fears (cognitive representation variables), exploration, commitment (behavioural variables). As predicted, lonely adolescents scored lower than socially embedded adolescents on future orientation variables applied to the relational and near future domains and lonely boys scored lower than lonely girls. However, effects were found only on the three future orientation motivational variables and not on the cognitive representation and behavioural variables. Contrary to prediction controlling for the effect of depressive experiences did not reduce the effect of loneliness on the future orientation variables, but reduced the tendency of adolescents to score higher on all future orientation variables in the instrumental than in the relational prospective domains. The contribution of these findings to the understanding of adolescent loneliness and future orientation was discussed and directions for future research were suggested.

Seginer R, Lilach E. Journal of Adolescence 2004;27:625-43. 